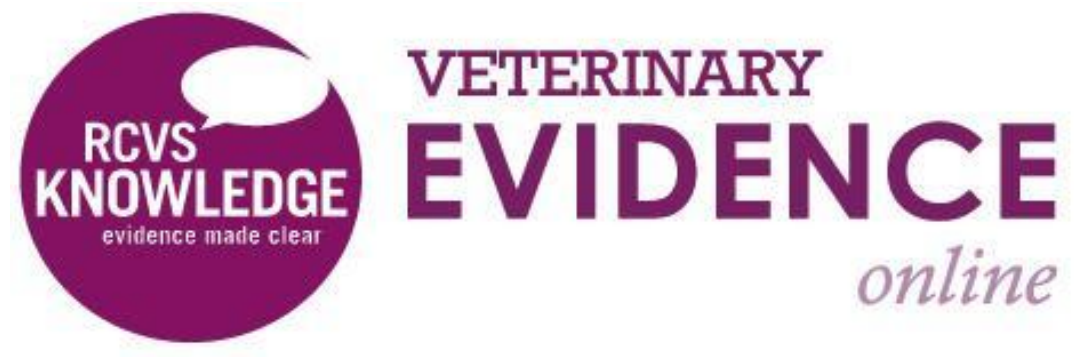

\title{
Are Adult Cats Fed on Wet Maintenance Diets Less at Risk of Developing Chronic Kidney Disease Compared to Adult Cats Fed on Dry Maintenance Diets?
}

\section{A Knowledge Summary by}

Catherine Anne M'Leonard BVetMed MSc MRes MRCVS $^{{ }^{1 *}}$

\footnotetext{
${ }^{1}$ University of Liverpool, Leahurst Campus, Chester High Road, Neston, Cheshire, CH64 7TE

*Corresponding Author (hlcmccar@liv.ac.uk)
}

ISSN: 2396-9776

Published: 2017

in: Vol 2, Issue 4

DOI: http://dx.doi.org/10.18849/ve.v2i4.130

Reviewed by: Nicola Ackerman (BSc(Hons), RVN, CertSAN, CertVNECC, VTS(Nutr), A1 V1 MBVNA) and Jacqueline Cole (BSc, BVetMed, MRCVS) 


\section{KNOWLEDGE SUMMARY}

\section{Clinical bottom line}

A comprehensive search of the available veterinary literature found three studies which assess whether feeding wet or dry maintenance diets place cats at an increased risk of chronic kidney disease (CKD) diagnosis. None of the three studies found any significant benefit of feeding either diet in reducing the risk of CKD. However, the criteria used to diagnose CKD was not standardised across any of the three studies. There is currently insufficient evidence that feeding a wet maintenance diet will help to reduce the risk of CKD but further studies are needed to assess whether diet can play some role in reducing the risk of CKD diagnosis.

\section{Question}

Are adult cats fed on wet maintenance diets less at risk of developing chronic kidney disease (CKD) compared to adult cats fed on dry maintenance diets?

\section{Clinical Scenario}

You diagnose chronic kidney disease (CKD) in a 12-year-old cat. The owner asks whether they can do anything to help to reduce the risk of their younger, 6-year-old cat getting CKD in the future. They are particularly interested in whether different types of food might help to reduce the risk of the disease.

\section{The Evidence}

The literature searches returned three papers which directly answered our PICO question. Two papers (Hughes et al., 2002; Greene et al., 2014) were case-control studies and one (Lefebvre, 2013) was a crosssectional study. None of the three studies found any significant difference in the prevalence of feeding wet, dry or a combination of wet and dry food to cats with CKD compared to healthy cats.

\section{Summary of the evidence}

\section{Hughes (2002)}

Population: $\quad$ Pet cats seen in five private practices or one university teaching hospital in Texas, USA whose owners were willing to participate in a telephone questionnaire.

Cats were divided into cases or controls. Cases were cats diagnosed with CKD between December 1994 and December 1995. CKD was diagnosed based on the presence of at least two of the following criteria:

- Blood urea nitrogen (BUN) $>35 \mathrm{mg} / \mathrm{dL}$ and/or serum creatinine $>1.9 \mathrm{mg} / \mathrm{dL}$

- Urine specific gravity (USG) $<1.035$ 


\begin{tabular}{|c|c|}
\hline & $\begin{array}{l}\text { - Palpation, radiography or ultrasound findings of kidneys } \\
\text { which were smaller than normal, larger than normal or } \\
\text { irregular/lumpy. } \\
\text { Control cats were those aged 7-years or above and free from renal } \\
\text { disease, classified as the presence of at least two of the following } \\
\text { criteria: } \\
\text { - BUN } \leq 35 \mathrm{mg} / \mathrm{dL} \text { and/or serum creatinine } \leq 1.9 \mathrm{mg} / \mathrm{dL} \\
\text { - USG } \geq 1.035 \\
\text { - Normal kidneys on palpation } \\
\text { Exclusion criteria for all cats were: } \\
\text { - Died within } 2 \text { weeks of first visit to the veterinary clinic } \\
\text { - Diagnosed with lower urinary tract disease, renal } \\
\text { cancer/calculi/other serious organ-system malfunction }\end{array}$ \\
\hline Sample size: & 38 cases and 56 control cats were included in the study \\
\hline Intervention details: & $\begin{array}{l}\text { Owners were contacted for a telephone interview between June } \\
1995 \text { and July } 1997 . \text { A variety of questions were asked including } \\
\text { previous activity levels; indoor/outdoor access; diet; and previous } \\
\text { health problems. All data were collected for the } 3 \text { years prior to } \\
\text { diagnosis. }\end{array}$ \\
\hline Study design: & Retrospective case-control study \\
\hline Outcome studied: & $\begin{array}{l}\text { Significant lifestyle risk factors were compared between cases and } \\
\text { controls using logistic regression modelling. Nutritional information } \\
\text { was collected in high-detail including type, frequency and volume of } \\
\text { food and treats fed, together with specific nutritional values } \\
\text { (metabolisable energy, protein, fat, fiber, ash, calcium, phosphorus, } \\
\text { potassium, sodium and magnesium in food). Factor analysis was } \\
\text { performed to determine relevant differences between variables } \\
\text { whilst allowing for potential interaction terms. }\end{array}$ \\
\hline $\begin{array}{l}\text { Main findings: } \\
\text { (relevant to PICO question): }\end{array}$ & $\begin{array}{l}\text { A questionnaire was used to record the type of food fed to each cat. } \\
\text { Owners could select several options if more than one type of food } \\
\text { was fed. Dry food was fed to } 95 \% \text { of cases and } 96 \% \text { controls. Semi- } \\
\text { moist food was fed to } 8 \% \text { cases and } 4 \% \text { controls and canned food } \\
\text { was fed to } 47 \% \text { cases and } 52 \% \text { controls. There was no significant } \\
\text { difference between feeding dry, semi-moist or canned food } \\
\text { between cases and controls in the univariable analysis ( } p \geq 0.25 \text { ). } \\
\text { A detailed list of possible foods were discussed during the interview } \\
\text { questionnaire. Nutritional content from the food was then } \\
\text { calculated using a software program (Animal Nutritionist, Version } \\
2.5, \text { N-Squared Incorporated \& Durango Software, Silverton, OR). } \\
\text { The following nutritional values within food was found to be } \\
\text { significant from the multivariable logistic regression: } \\
\text { - Increasing fibre content had a protective effect, with an } \\
\text { odds ratio (OR) of } 0.8 \text { ( } p=0.03 \text { or } 0.02 \text { depending on the } \\
\text { model) } \\
\text { Ad libitum feeding increased the odds of CKD development } \\
\text { (OR 4.1, } p=0.02 \text { in one model; OR } 5.5, p=0.02 \text { in a second }\end{array}$ \\
\hline
\end{tabular}




\begin{tabular}{|c|c|}
\hline & $\begin{array}{l}\text { model) } \\
\text { - A new variable from the factor analysis, termed "Factor- } 2 \text { " } \\
\text { also had a protective effect with an OR of } 0.4(p=0.045) \text {. This } \\
\text { factor was a composition of the fibre, magnesium, protein, } \\
\text { sodium and ash content of the diet. } \\
\text { - Metabolisable energy (kcal), fat, calcium, phosphorus and } \\
\text { potassium content of the diet were not significant risk } \\
\text { factors }\end{array}$ \\
\hline Limitations: & $\begin{array}{l}\text { - The criteria used to diagnose CKD in the case cats within this } \\
\text { study does not fit with current IRIS guidelines (International } \\
\text { renal interest society, 2013). Only } 26 \text { cats met the criteria } \\
\text { for both (1) BUN > } 35 \mathrm{mg} / \mathrm{dL} \text { and/or serum creatinine }>1.9 \\
\text { mg/dL; and (2) USG < } 1.035 .12 \text { cats were included as cases } \\
\text { with only one of these two criteria plus gross irregularity on } \\
\text { the kidney on either palpation or diagnostic imaging. } \\
\text { Current IRIS guidelines are dependent upon creatinine and } \\
\text { USG results rather than BUN or kidney irregularities. } \\
\text { Futhermore, these guidelines provide a lower creatinine } \\
\text { cutoff value of } 1.6 \text { mg/dL. There is a large potential for } \\
\text { misclassification bias between cases and controls in this } \\
\text { study and is one of the greatest limitations to this study. } \\
\text { The owner questionnaires asked information such as diet } \\
\text { and activity levels from the cat's previous } 3 \text {-year history } \\
\text { prior to diagnosis. There was a median time from diagnosis } \\
\text { to interview of } 7 \text { months (range } 0.9-25 \text { ) for controls and } 5 \\
\text { months (range } 1-24 \text { ) for cases. This is a potential relapsed } \\
\text { time of between } 3 \text { and } 5 \text { years ( } 3 \text { year history prior to } \\
\text { diagnosis plus timeframe from diagnosis to interview of } 1 \\
\text { month or } 25 \text { months respectively). The reliability of owner } \\
\text { recall from such a historical timeframe has to be questioned, } \\
\text { especially when considering the complexity of some of the } \\
\text { questions. } \\
\text { Finally, the selection of cats from veterinary practices with a } \\
\text { large feline bias and the prerequisite for owners to be } \\
\text { available and compliant for telephone interviews, could } \\
\text { have created a selection bias amongst the cats which were } \\
\text { available to participate in the study. } \\
\text { which could then be listed as "dry food", "canned food", } \\
\text { "semi-moist food", "treats", "cooked meat" or "milk". The } \\
\text { authors haven't clarified what type of food was counted } \\
\text { within the "semi-moist" category but it could be assumed } \\
\text { that the "canned" food is equivalent to wet food. Owners } \\
\text { could also list several different types of food, therefore } \\
\text { statistical interpretation was overly complex. }\end{array}$ \\
\hline
\end{tabular}




\begin{tabular}{|c|c|}
\hline \multicolumn{2}{|l|}{ Lefebvre (2013) } \\
\hline Population: & $\begin{array}{l}\text { Any canine or feline patient within } 815 \text { Banfield Pet Hospitals in the } \\
\text { United States which was first diagnosed as having CKD in } 2011 \text { or } \\
\text { 2012. Prior to inclusion in the study, participants needed to have } \\
\text { visited one of the study hospitals on at least one other occasion. } \\
\text { There was no information provided on the criteria used for CKD } \\
\text { diagnosis. }\end{array}$ \\
\hline Sample size: & 11,752 cats and 7,293 dogs were included. \\
\hline Intervention details: & $\begin{array}{l}\text { Clinical records were analysed to collect information on the patients: } \\
\text { 1) Age, bodyweight, sex, reproductive status and breed size for } \\
\text { dogs } \\
\text { 2) Biochemistry values, USG and evidence of concurrent } \\
\text { diseases was noted from the visit closest to the CKD } \\
\text { diagnosis } \\
\text { 3) Type of diet fed (wet, dry, mixed). } \\
\text { The reproductive status, breed size, and diet types in the CKD } \\
\text { patients were compared to the general population of cats and dogs } \\
\text { which attended any Banfield Pet Hospital over the same timeframe. }\end{array}$ \\
\hline Study design: & Cross-sectional study \\
\hline Outcome studied: & $\begin{array}{l}\text { The authors compared the demographical and clinicopathological } \\
\text { features from the clinical records of patients diagnosed with CKD. }\end{array}$ \\
\hline $\begin{array}{l}\text { Main findings: } \\
\text { (relevant to PICO question): }\end{array}$ & $\begin{array}{l}\text { There was no difference in the type of food consumed (wet, dry, } \\
\text { mixed) between cats and dogs with CKD and the general pet } \\
\text { population which attended the Banfield Pet Hospitals. No further } \\
\text { details on how many animals were fed wet or dry food were } \\
\text { provided. We also have no details on the age or breed of the general } \\
\text { pet population, or how these animals were selected for inclusion in } \\
\text { the study. Therefore, this cannot be considered as a true control } \\
\text { group for this study. } \\
\text { The presence of periodontal disease, cystitis, hyperthyroidism, } \\
\text { diabetes mellitus and hypertension were all significantly (p<0.01) } \\
\text { higher in cats and dogs with CKD than in the general population. }\end{array}$ \\
\hline Limitations: & $\begin{array}{l}\text { The study results are presented in a short-communication format } \\
\text { rather than a traditional journal article. As such, there is a } \\
\text { substantial lack of information provided. Of relevance to our PICO } \\
\text { question, we are not provided with the following information: } \\
\text { 1) The criteria used to diagnose CKD } \\
\text { 2) Duration of feeding the dry or wet food } \\
\text { 3) Statistical results for type of food fed }\end{array}$ \\
\hline
\end{tabular}

Greene (2014)

Population: Cats brought to any Banfield Pet Hospital in the United States from 


\begin{tabular}{|c|c|}
\hline & $\begin{array}{l}1^{\text {st }} \text { January } 2010 \text { to } 31^{\text {st }} \text { December } 2010 \text {. All cats must have visited a } \\
\text { Banfield Pet Hospital at least once prior to their inclusion in the } \\
\text { study. } \\
\text { Cats were divided into cases and controls. } \\
\text { Inclusion criteria for cases: } \\
\text { - Known age, breed and reproductive status } \\
\text { - Serum creatinine concentration }>1.6 \mathrm{mg} / \mathrm{dL} \text { (measured } \\
\text { - within } 30 \text { days of CKD diagnosis) } \\
\text { - USG }<1.035 \text { (measured within } 30 \text { days of CKD diagnosis) } \\
\text { Inclusion criteria for controls: } \\
\text { - Known age, breed and reproductive status } \\
\text { - No previous CKD diagnosis } \\
\text { - Serum creatinine concentration }<2.2 \mathrm{mg} / \mathrm{dL} \text { (measured } \\
\text { within } 30 \text { days of CKD diagnosis) } \\
\text { Controls were randomly selected to match the case cats by age at } \\
\text { study entry ( } \pm 6 \text { months) in a } 1: 1 \text { ratio. } \\
\text { The authors state that at the time of writing, the Banfield Pet } \\
\text { Hospital network included } 755 \text { primary care veterinary hospitals in } \\
43 \text { states in the USA. }\end{array}$ \\
\hline Sample size: & $\begin{array}{l}\text { - 6,747 cats were diagnosed with CKD during the study period } \\
\text { but only } 1,230 \text { (18.2\%) met the criteria for inclusion as a } \\
\text { case. The authors state that typical reasons for exclusion } \\
\text { were errors in reporting birth date, breed or unspecified } \\
\text { reproductive status. Case cats: } 408 / 1,230 \text { cats (diet } \\
\text { information was available from } 408 \text { cases) } \\
\text { - Control cats: } 424 / 1,230 \text { cats (diet information was available } \\
\text { from } 424 \text { controls) }\end{array}$ \\
\hline Intervention details: & $\begin{array}{l}\text { Medical records were retrospectively collected from all cats included } \\
\text { in the study. Of relevance to our PICO question, data was analysed } \\
\text { on: } \\
\text { 1) Type of diet fed within } 1 \text { year prior to study entry (as either } \\
\text { wet, dry or wet and dry food) when available } \\
\text { 2) Clinical signs of CKD at study entry and in the latest visit 6-12 } \\
\text { months prior to study entry. Diagnosis of predisposing or } \\
\text { concurrent diseases (for example, arthritis, diabetes } \\
\text { mellitus, hyperthyroidism, periodontal disease etc). }\end{array}$ \\
\hline Study design: & Retrospective case-control study \\
\hline Outcome studied: & $\begin{array}{l}\text { The outcome measure was a diagnosis of CKD based on serum } \\
\text { creatinine concentration and USG values at one-point in time. } \\
\text { Logistic regression was used to investigate which factors make a } \\
\text { diagnosis of CKD more likely amongst cats that present to a }\end{array}$ \\
\hline
\end{tabular}




\begin{tabular}{|c|c|}
\hline & veterinary clinic. \\
\hline $\begin{array}{l}\text { Main findings: } \\
\text { (relevant to PICO question): }\end{array}$ & 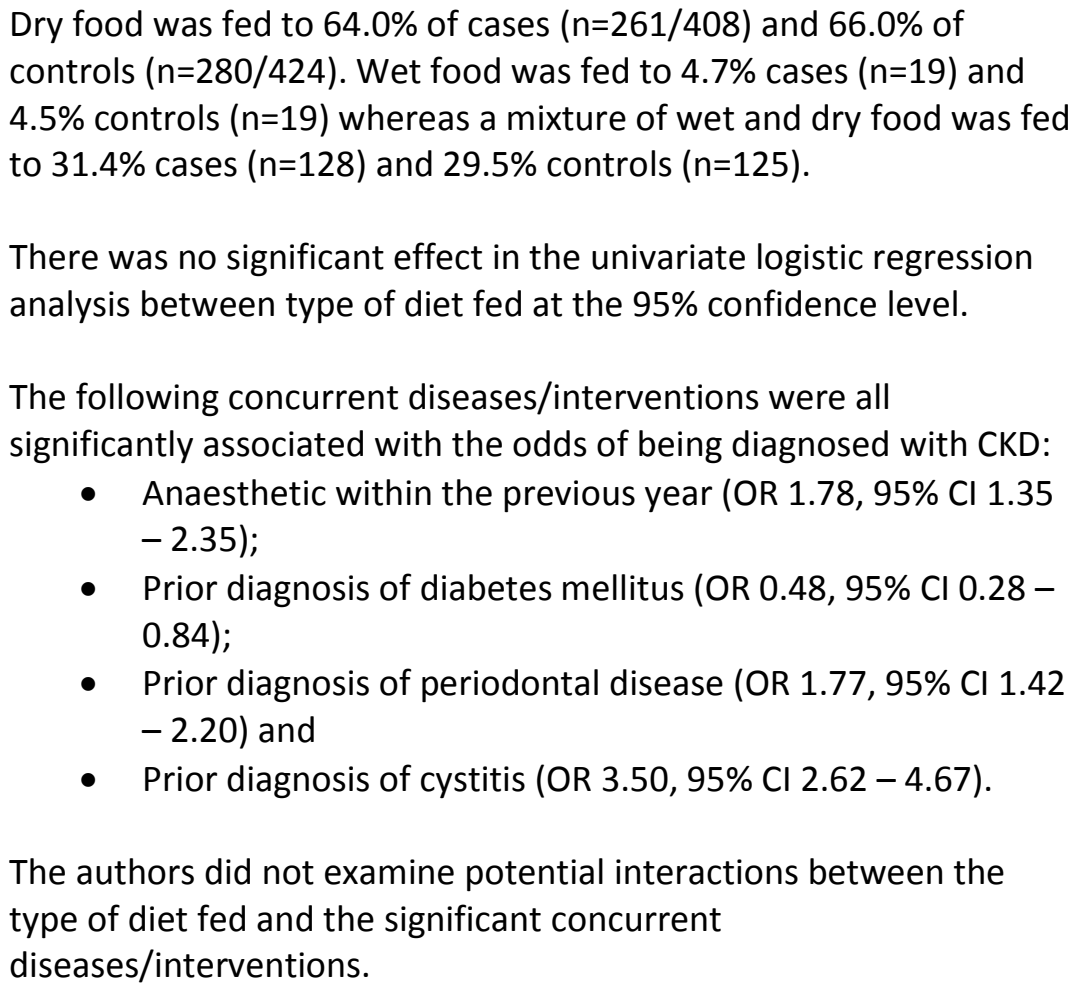 \\
\hline Limitations: & $\begin{array}{l}\text { One major limitation of this study is the disparity in inclusion criteria } \\
\text { between cases and controls. The case cats needed to have a } \\
\text { creatinine concentration above } 1.6 \mathrm{mg} / \mathrm{dL} \text { which is in accordance } \\
\text { with current IRIS guidelines for classification of stage } 2 \text { CKD (defined } \\
\text { as those cats with mild renal azotemia). However, the control cats } \\
\text { could have a creatinine concentration up to the upper reference } \\
\text { limit from the laboratory of } 2.2 \mathrm{mg} / \mathrm{dL} \text {. We are not provided with } \\
\text { average creatinine or USG values for the controls and so have no } \\
\text { information on how the controls would be classified within the } \\
\text { updated IRIS guidelines. Without this information, there could be a } \\
\text { potential misclassification of the controls creating biased results. } \\
\text { Although a reasonably large number of cats were included in this } \\
\text { study, the number of cases included (n=1,230) is only } 18.2 \% \text { of the } \\
6,747 \text { cats diagnosed with CKD during the study period. The authors } \\
\text { explain the reasons for this which include noncompliance with } \\
\text { inclusion criteria, particularly an absence of birth date, breed and } \\
\text { reproductive status. This seems to be a strict criteria precluding } \\
\text { many cases from being included. The authors fail to explain whether } \\
\text { the case cats were representative of the CKD population which was } \\
\text { not included in the study. Furthermore, there are potential } \\
\text { interaction terms with respect to our PICO question if for example, } \\
\text { there was an association between unknown birth date (for example } \\
\text { in a feral cat) and the feeding of dry food. } \\
\text { Of particular relevance to our PICO question, we are not able to } \\
\text { understand the relevance of diet on the significant concurrent } \\
\text { diseases which are risk factors for CKD diagnosis. For example, one } \\
\text { typical post-periodontal disease management would be to }\end{array}$ \\
\hline
\end{tabular}


encourage the feeding of dry food to minimise further plaque development. Conversely, the feeding of wet food is often recommended after a cystitis diagnosis. The authors have not evaluated whether diet fed is either an interaction term or confounder for CKD development with concurrent diseases.

\section{Appraisal, application and reflection}

The feeding of dry food to cats has been hypothesised by some authors to cause CKD due to a low water content within the food (see for example, Greene et al., 2014). From the three relevant papers found within this literature search, only Hughes et al. (2002) comprehensively examined the effect of nutritional parameters within food whereas the other two papers examined clinical records for descriptions of food given, as noted by the owners. Unfortunately, the small sample size and potential misclassification bias (by not abiding by current IRIS guidelines to diagnose CKD) within Hughes et al. (2002) reduces its reliability. Ultimately, none of these three papers provided conclusive evidence to answer the PICO question.

For the general practitioner, it is encouraging to find evidence that certain nutritional parameters may be beneficial in delaying the onset of CKD diagnosis. Hughes et al. (2002) found that an increased fibre content in the diet and the ambiguous "factor-2" were both protective in delaying CKD development whereas adlibitum feeding was detrimental. Whilst performing the literature search, a small number of additional papers were uncovered which appeared to suggest that diet could help to reduce the risk of CKD development (DiBartola et al., 1993; Frantz et al., 2007; Lane et al., 2012; Geddes et al., 2016), although these were all excluded from the current PICO question as they did not look at the difference between wet and dry food. Further research, including a broader literature search, is needed in this area.

There was a significant association between CKD diagnosis and a history of previous anaesthetics, periodontal disease, hyperthyroidism, hypertension, cystitis and diabetes mellitus. This is perhaps unsurprising since some cats may be more likely to present for more acute problems such as urinary tract infections than chronic conditions such as CKD. Moreover, a previous, acute illness such as cystitis, or chronic condition like hyperthyroidism, may facilitate more careful veterinary monitoring by both owners and vets. However, none of these studies analysed whether diet fed was a significant interaction term with the comorbidity. This is a frustrating omission given the frequency of veterinary advice recommending a diet change after for example, lower urinary tract conditions or periodontal disease. Another interesting Knowledge Summary could be developed to look at the usefulness of wet food on preventing further episodes of feline lower urinary tract disease.

This PICO question has an underlying assumption that all wet maintenance diets, and all dry maintenance diets, can be treated equally with regards to water content and nutritional value. To the author's knowledge, there have been no studies performed which confirm this assumption. Arguably, the plethora of commercial diets available for cats makes this an unrealistic assumption. Furthermore, the proportion of cat owners amongst the general cat-owning population who change diets or feed a mixture of wet and dry food is unknown. Therefore, it seems unlikely that any retrospective study into this PICO question would yield sufficient power to answer this question with certainty. Furthermore, it should be acknowledged that these studies have looked at risk factors for CKD diagnosis, not the onset of kidney damage. It is possible that cats which obtain an increased water content, by for example, eating a wet diet, are diagnosed later in the disease process due to a relative compensation for kidney damage. Alternatively, it is theoretically possible that a risk factor may create such severe kidney disease that cats are never presented to veterinary practices. Therefore, the potential biases of using the veterinary-presenting population of cats should be considered when considering the risk factors for CKD. Ultimately, a prospective randomised control trial (RCT) would provide greatest evidence on whether the feeding of wet or dry diets can reduce the risk of kidney damage. Further research into this area is needed to ensure that vets aren't inadvertently placing cats at an increased risk of CKD when suggesting a diet change after being diagnosed with periodontal disease, cystitis or several 
other comorbidities.

\section{Methodology Section}

\begin{tabular}{|c|c|}
\hline & \\
\hline $\begin{array}{r}\text { Databases searched and dates } \\
\text { covered: }\end{array}$ & $\begin{array}{l}\text { CAB Abstracts on OVID interface (1973 - Week } 06 \text { 2017); PubMed } \\
\text { (1973 - Week } 13 \text { 2017) }\end{array}$ \\
\hline Search terms: & $\begin{array}{l}\text { CAB Abstracts: } \\
\text { (cat OR cats OR feline OR felines OR queen OR tom) AND (chronic } \\
\text { renal failure OR chronic renal disease OR chronic renal insufficiency } \\
\text { OR chronic kidney insufficiency OR chronic kidney failure OR chronic } \\
\text { kidney disease) AND (diet OR food OR maintenance diet OR } \\
\text { maintenance diets) } \\
\text { LIMITED to English language } \\
\text { NCBI PubMed: } \\
\text { (cat OR cats OR feline OR felines) AND (chronic renal failure OR } \\
\text { chronic renal disease OR chronic renal insufficiency OR chronic } \\
\text { kidney insufficiency OR chronic kidney failure OR chronic kidney } \\
\text { disease OR renal failure OR kidney disease) AND (diet OR } \\
\text { maintenance diet OR maintenance diets) } \\
\text { LIMITED to English language; Species: Other Animals; Subjects: } \\
\text { Veterinary Science }\end{array}$ \\
\hline Dates searches performed: & CAB Abstracts 21/02/2017; Pubmed 28/03/2017 \\
\hline
\end{tabular}

\section{Exclusion / Inclusion Criteria}

Inclusion and exclusion criteria were determined prior to performing the search. Filters were added after a preliminary search returned a large number of irrelevant results. The suitability of articles was initially assessed through examination of the title and abstract. Full-text articles were then retrieved and examined.

\begin{tabular}{|l|l|}
\hline Exclusion: & $\begin{array}{l}\text { - } \begin{array}{l}\text { Human literature was excluded as this was deemed } \\
\text { irrelevant to our PICO question. }\end{array} \\
\text { - Review papers aside from systematic reviews }\end{array}$ \\
\hline Inclusion: & $\begin{array}{l}\text { Any relevant primary veterinary research or systematic review which } \\
\text { examined the association between feeding dry maintenance food or } \\
\text { wet maintenance food and the development of chronic kidney } \\
\text { disease. }\end{array}$ \\
\hline
\end{tabular}

\begin{tabular}{|c|c|c|c|c|c|c|}
\hline \multicolumn{7}{|c|}{ Search Outcome } \\
\hline Database & $\begin{array}{l}\text { Number } \\
\text { of } \\
\text { results }\end{array}$ & $\begin{array}{l}\text { Excluded - } \\
\text { duplicates }\end{array}$ & $\begin{array}{l}\text { Excluded - did } \\
\text { not answer } \\
\text { PICO question }\end{array}$ & $\begin{array}{c}\text { Excluded - diet } \\
\text { as treatment } \\
\text { not prevention }\end{array}$ & $\begin{array}{l}\text { Excluded - no } \\
\text { assessment of } \\
\text { wet or dry food }\end{array}$ & $\begin{array}{c}\text { Total } \\
\text { relevant } \\
\text { papers }\end{array}$ \\
\hline
\end{tabular}




\begin{tabular}{|l|c|c|c|c|c|c|}
\hline CAB Direct & 117 & 0 & 59 & 51 & 5 & 2 \\
\hline $\begin{array}{l}\text { NCBI } \\
\text { PubMed }\end{array}$ & 124 & 18 & 61 & 38 & 6 & 1 \\
\hline
\end{tabular}

\section{CONFLICT OF INTEREST}

The authors declare no conflicts of interest.

I would like to thank Clare Boulton for assistance in running the searches and finding complete copies of the papers and Bridget Sheppard for assistance throughout the process.

\section{REFERENCES}

1. DiBartola, S. P., Buffington, C. A., Chew, D. J., et al., (1993) Development of chronic renal disease in cats fed a commercial diet. Journal of the American Veterinary Medical Association, 202 (5), 744-751

2. Frantz, N. Z., Yamka, R. M. and Friesen, K. G. (2007) The effect of diet and lysine:calorie ratio on body composition and kidney health in geriatric cats. International Journal of Applied Research in Veterinary Medicine, 5 (1), 25-36

3. Geddes, R. F., Biourge, V., Chang, et al., (2016) The effect of moderate dietary protein and phosphate restriction on calcium-phosphate homeostasis in healthy older cats. Journal of Veterinary Internal Medicine, 30 (5), 1690-1702. DOI: http://dx.doi.org/10.1111/jvim.14563

4. Greene, J. P., Lefebvre, S. L., Wang, M., et al., (2014) Risk factors associated with the development of chronic kidney disease in cats evaluated at primary care veterinary hospitals. Journal of the American Veterinary Medical Association, 244 (3), 320-327. DOI: http://dx.doi.org/10.2460/javma.244.3.320

5. Hughes, K. L., Slater, M. R., Geller, S., et al., (2002) Diet and lifestyle variables as risk factors for chronic renal failure in pet cats. Preventive Veterinary Medicine, 55 (1), 1-15

DOI: http://dx.doi.org/10.1016/S0167-5877(02)00088-0

6. International renal interest society (2013) IRIS Staging of CKD ( modified 2013 ), Novartis animal health, 1-8.

7. Lane, E. P., Miller, S., Lobetti, R., et al., (2012) Effect of diet on the incidence of and mortality owing to gastritis and renal disease in captive cheetahs (Acinonyx jubatus) in South Africa. Zoo Biology, 31 (6), 669-682. DOI: http://dx.doi.org/10.1002/zoo.20431

8. Lefebvre, S. (2013) Clinical findings in cats and dogs with chronic kidney disease. Veterinary Focus, 23 (3), 26-27 


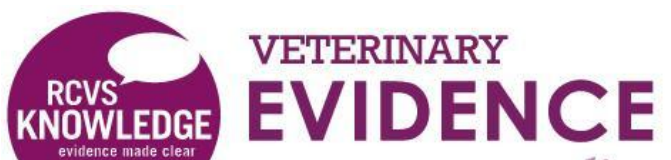 \\ online}

\section{Intellectual Property Rights}

Authors of Knowledge Summaries submitted to RCVS Knowledge for publication will retain copyright in their work, and will be required to grant to RCVS Knowledge a non-exclusive license of the rights of copyright in the materials including but not limited to the right to publish, re-publish, transmit, sell, distribute and otherwise use the materials in all languages and all media throughout the world, and to license or permit others to do so.

\section{Disclaimer}

Knowledge Summaries are a peer-reviewed article type which aims to answer a clinical question based on the best available current evidence. It does not override the responsibility

of the practitioner. Informed decisions should be made by considering such factors as individual clinical expertise and judgement along with patient's circumstances and owners' values. Knowledge Summaries are a resource to help inform and any opinions expressed within the Knowledge Summaries are the author's own and do not necessarily reflect the view of the RCVS Knowledge.

Veterinary Evidence and EBVM Network are RCVS Knowledge initiatives. For more information please contact us at editor@veterinaryevidence.org

RCVS Knowledge is the independent charity associated with the Royal College of Veterinary Surgeons (RCVS). Our ambition is to become a global intermediary for evidence based veterinary knowledge by providing access to information that is of immediate value to practicing veterinary professionals and directly contributes to evidence based clinical decision-making.

\section{www.veterinaryevidence.org}

RCVS Knowledge is a registered Charity No. 230886. 
Registered as a Company limited by guarantee in England and Wales No. 598443.

Registered Office:

Belgravia House

62-64 Horseferry Road

London SW1P 2AF

(a) (1)

This work is licensed under a Creative Commons Attribution 4.0 International License. 